at the end of a "pre-S.1 course": mathematics, science and technical drawing. The main answer seemed to lie in the establishment by the colleges of standards of entry high and broad enough to ensure a much greater chance of success than is usual at present. These standards should apply to all National Certificate aspirants.

Summing up, Mr. Part visualized openings for some $3,500-4,000$ sandwich course students a year from sixth forms, provided they had the necessary advanced-level qualifications. Those who had four appropriate passes at ordinary level of General Certificate of Education were eligible to enter directly into the second year of the National Certificate course and could thereby get their Ordinary National Certificate by, say, $18 \frac{1}{2}$ and then go either to the university by winning a Technical State Scholarship or to any of the advanced technical college courses. For those who stopped short of the General Certificate of Education or took a different route there was a whole variety of courses.

\title{
MANAGEMENT OF SMALL FIRMS
}

$\mathrm{T}^{\mathrm{H}}$ $\mathrm{HE}$ difficulties of providing efficient management control in small engineering firms have been analysed by L. Fontaine, J. W. Walker and W. R. Spencer, of Urwick, Orr and Partners; they also make suggestions for introducing and using effective controls*.

In their paper the authors emphasize that, since nearly half of British industrial activity derives from small businesses, it is essential to our economic well. being that they should be well managed. If the manager is the only executive with real management ability, then he is forced to take responsibility for all sides of the business. His company is virtually a 'one-man-band' and its activities are limited to what he can personally achieve in his waking hours each day.

It is a truism that a business cannot stay still ; it must either grow larger or smaller. To meet the pressing problems of growth the manager is compelled to bring in (or promote) individuals who are capable of taking over the full responsibility for specific sides of the business. This action immediately causes new organizational problems, and the manager has to readjust his thinking and re-orientate his ideas of how he should run his business. The core of his problem is to build up a management team and to manage his business through them. His task is to set the objectives and to keep watch over the attain. ment (or otherwise) of these objectives by his sub-

* Management Control of Small Engineering Firms. Pp. 39. (Lon don: Institution of Mechanical Engincers, 1958.) 2s. $6 \dot{d}$. ordinates. To many managers of small businesses this can be a most difficult discipline; it is so much easier to continue to do things oneself than to learn how to ensure that others do them instead.

Although management control techniques are no substitute for dynamic leadership, they are, nevertheless, an inescapable part of the mechanisms of modern management. The principles governing these techniques have been tested and proved over and over again. The wise manager of the small business to-day will obtain a clear understanding of these principles before he applies them to specific problems; he will not import 'systems' as such, for they are unlikely to fit and will therefore fail.

The management control techniques considered by the authors are: first, the personal problems arising from the need to delegate responsibility to assistants ; secondly, the problems of how to control the design and manufacturing activities; and thirdly, the control of finance and costs and methods of ensuring profitability.

These three separate sets of management control techniques are closely interlinked and each technique is an essential piece in the whole management control pattern. It is possible to introduce isolated control techniques here and there, but the manager who is determined to set his growing business on a continuously successful course will not rest content until he has introduced adequate control over all sides of his business.

\section{THE COMMONWEALTH FUND}

$\mathrm{T}$ HE thirty-ninth annual report of the Common. wealth Fund (pp. xii +41 . New York: The Commonwealth Fund, 1957) covers the year ended June 30, 1957, in which 54 grants were voted totalling $3,808,913$ dollars, more than 90 per cent being towards the general area of health. The section dealing with medical education and community hoalth, for which 23 grants, totalling $2,009,346$ dollars, were voted, of which 11 were new, discusses the close relation and interdependence between social institutions responsible for training health personnel and those institutions and agencies through which health services are made available to the community. Following a review of the Fund's activities by the president, Mr. M. P. Aldrich, the Board decided that for the next fow years major emphasis in the health field should remain on medical education ; and its interest in community health, in medical research, in nursing and medical fellowships and awards, in related publications and in the programme of international fellowships should continue.
Cornell University received a grant for extending research on care of patients in the Comprehensive Care and Teaching Programme, which embraces both the traditional modical setting and the community and family setting. It should indicate the extent to which, and the manner in which, the application of medical skills is influenced by differing factors in the two environments. The University of Virginia School of Medicine is extending its pilot study of the diagnostic or general clinic as it affects the reorganization of tho out-patient department, and the University of Washington School of Nursing received a grant to complete a study of nursing education. Tulane University School of Medicine is studying the personality, emotional and motivational problems of medical students, and a study at the University of Chicago and at Loyola University, Chicago, is designed to develop tests for determining skill in clinical observation, in medical diagnosis and in dealing with professional situations. Grants were also made to the Faculty of Medicine at MeGill 